\title{
Hydrogen Gas Sensing Properties of AgNPs-Doped Titania Nanotubes by Electroless Deposition
}

\author{
Haidar Hameed Hamdan ${ }^{1}$, Ghuson Hameed Mohammed ${ }^{2}$ \\ ${ }^{1}$ Physics Department, College of Science/ Baghdad University, Baghdad, Iraq
}

\begin{abstract}
Titania nanotubes thin films have been prepared by electrochemical anodization of Ti foil at room temperature ( $\left.25^{\circ} \mathrm{C}\right)$, in ethylene glycol base electrolyte with $0.5 \mathrm{wt} \% \mathrm{NH}_{4} \mathrm{~F}$ and $4 \mathrm{wt} \%$ deionized water at $30 \mathrm{~V}$ at time $3 \mathrm{hr}$ and then $\mathrm{AgNPs}-\mathrm{doped} \mathrm{TiO}_{2}$ nanotube arrays at different deposition ratios $(0.3,0.5,0.7,0.9 \mathrm{wt} \%)$ were carried out by electroless deposition. These tubes are well aligned and organized into high-density uniform arrays. The average tube diameter, ranging in size from 61 to $74 \mathrm{~nm}$, the length of the tube $2.13 \mu$, and ranging in size of wall thickness from 21 to $29 \mathrm{~nm}$. A possible growth mechanism is presented. The TiO ${ }_{2}$ nanotubes were characterized by $X$-ray diffraction (XRD), scanning electron microscope (FESEM) and energy dispersive X-ray spectroscopy (EDX). Gas sensors based on AgNPs/TiO ${ }_{2}$ nanotube arrays thin films were fabricated, and their sensing properties were investigated. The AgNPs/TiO ${ }_{2}$ nanotube sensor demonstrated a good sensitivity at different concentration hydrogen atmospheres ranging from (15, 30, 45, $60,75 \mathrm{ppm}) \mathrm{H}_{2}$. A temperature-dependent sensing from $25^{\circ} \mathrm{C}$ to $300^{\circ} \mathrm{C}$ was also found with an applied voltage was constant at $6 \mathrm{~V}$.
\end{abstract}

Keywords: $\mathrm{TiO}_{2}$ nanotubes; anodization; ethylene glycol, electroless, gas sensor, $\mathrm{H}_{2}, \mathrm{AgNPs}-\mathrm{doped} \mathrm{TiO}_{2}$.

\section{Introduction}

Hydrogen has numerous applications in industry, such as chemical production, fuel cell technology, and rocket engines ${ }^{[1]}$. However, the flammable and explosive properties of hydrogen gas make its detection an important issue ${ }^{[2]}$. Therefore, today a wide range of investigations are being carried out toward the development of highly sensitive, compact, low cost, and reliable hydrogen sensors ${ }^{[3]}$. In order to overcome the disadvantages of commercially available hydrogen sensors ${ }^{[4]}$, different detection principles, methods, and materials have been utilized to manufacture sensors during the last few decades. The basic categories of sensors include catalytic sensors, electrochemical sensors, resistive palladium and palladium alloy sensors, field effect transistors, Schottky diodes, and semiconductor metal oxide sensors ${ }^{[5]}$. Metal oxide films have been playing an increasingly important role in the last few years as sensing materials for various gases ${ }^{[5]}$. $\mathrm{TiO}_{2}$ based gas sensors have been widely used because of their inert surface properties and high sensing abilities ${ }^{[6]}$. Recently, many nanotechnological approaches have been employed to enlarge the surface area of $\mathrm{TiO}_{2}$ without increasing the device dimensions ${ }^{[7]}$. Highly ordered $\mathrm{TiO}_{2}$ nanotubes were first synthesized using an anodization process by Grimes et al., using hydrofluoric acid (HF) electrolyte ${ }^{[8]}$. Thereafter, further studies succeeded in controlling and extending the nanotube morphology ${ }^{[9]}$, the length and pore size ${ }^{[10]}$, and the wall thickness ${ }^{[1]}$. The choice of electrolyte plays a critical role in determining the resultant nanotube array.

Titanium dioxide $\left(\mathrm{TiO}_{2}\right)$ is an important multifunctional material being used as photo-catalyst in solar cells, for the production of hydrogen, as a corrosion-protective coating, as an optical coating, as a gate insulator in MOSFETs, etc. ${ }^{[12,13]}$. In recent years a large number of contributions have reported the extraordinary sensitivity of $\mathrm{TiO}_{2}$ towards $\mathrm{H}_{2}{ }^{[14]}$. $\mathrm{TiO}_{2}$ also shows good sensing properties to $\mathrm{CO}{ }^{[15]}$, ethanol ${ }^{[16]}$, methane ${ }^{[17]}$, etc. and have an advantage of being chemically stable at high temperatures which makes it a good candidate for gas sensing applications ${ }^{[18]}$. However, the main disadvantage of these gas sensors is the inability to distinguish between gases, but it has been reported that the selectivity could be improved by dopants ${ }^{[19]}$. Doped silver nitride-based $\mathrm{TiO}_{2}$ nanotubes layer are relatively easy to obtain, to act as a host material for these applications [20] The high ability of this material to form stable $\mathrm{TiO}_{2}$ nanotubes layer, allied to the silver acting as a metallic nanostructure precursor, results in a promising new hybrid structure: self-growth metallic thin films over a $\mathrm{TiO}_{2}$ nanotubes layer surface, obtained by electroless method. The electroless promotes the silver diffusion up to the $\mathrm{TiO}_{2}$ nanotubes layer surface and then the reaction.

In this study, we synthesize highly-ordered $\mathrm{TiO}_{2}$ nanotubes by anodic oxidation of titanium foil in an aqueous solution containing $(0.5 \mathrm{wt} \%)$ of $\mathrm{NH}_{4} \mathrm{~F}$ in ethylene glycol $(95.5 \mathrm{wt} \%)$ with (4wt \%) DI water at (3hours) room temperature, 30 Vdc. Then silver nanoparticles doped on titania nanotubes sample at different deposition rations by electroless method, and investigate their hydrogen sensing properties in terms of the temperature and the hydrogen concentration. The hydrogen sensing mechanism of the $\mathrm{TiO}_{2}$ nanotubes will be explained in detail.

\section{Experimental}

\subsection{Preparation of titania nanotubes $\mathrm{TiO}_{2}$}

Pure titanium foil (99.7\% purity, $0.25 \mathrm{~mm}$ in thickness) purchased from Sigma Aldrich and cut into the desired size $(20 \times 20 \mathrm{~mm})$. A direct current power supply (Agilent E3612A) was used as the voltage source for the anodization. The anodization process was carried out in a homemade plexi glass cell with two electrode configuration; titanium foil as the working electrode and $0.1 \mathrm{~mm}$ thick. Platinum mesh $(20 \times 30 \mathrm{~mm})$ as the counter electrode under constant potential at room temperature $\left(\sim 25^{\circ} \mathrm{C}\right)$. The titanium sheets were sonicated in acetone and ethanol each for (15) minutes, followed by rinsing with de-ionized (DI) water to remove the impurities and then drying in $\left(\mathrm{N}_{2}\right)$ gas. The anodization set-up is shown in Figure (1). The anodization was carried 


\section{International Journal of Science and Research (IJSR) \\ ISSN (Online): 2319-7064 \\ Index Copernicus Value (2013): 6.14 | Impact Factor (2014): 5.611}

out at $30 \mathrm{Vdc}$, the cell electrolyte was $(0.5 \mathrm{wt} \%)$ of $\mathrm{NH}_{4} \mathrm{~F}$ in ethylene glycol $(95.5 \mathrm{wt} \%)$ with (4wt \%) DI water at (3hours). The prepared samples were rinsed immediately with (DI) water for several minutes and dried with high pressure $\left(\mathrm{N}_{2}\right)$ gas.

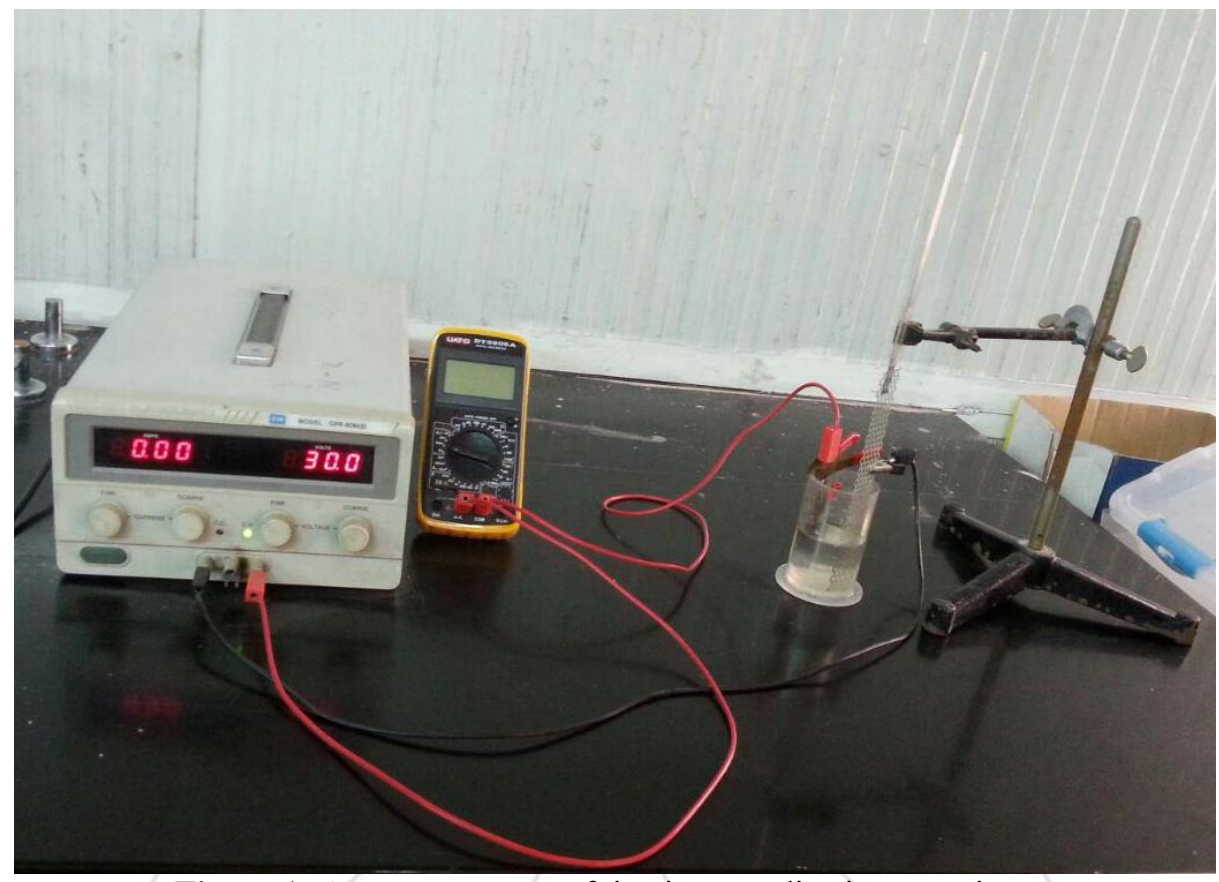

Figure 1: Apparatus set-up of titanium anodization experiment

\subsection{Preparation of $\mathrm{AgNPs} / \mathrm{TiO}_{2}$ catalysts}

After anodizing of titanium, the samples were ultrasonically cleaned in distilled water for 10-20 min to remove surface debris. Then the $\mathrm{TiO}_{2}$ nanotubes sample were immerged into the bath for electroless deposition.

This technique was composed of two steps. The first step was the titania nanotubes sample was immersed into AgNPs solution, which was prepared by dissolving the silver nitrate $(2 \mathrm{~g})$ in the water $(50 \mathrm{~mL})$, at room temperature and different time deposition $(5,10,15,20$ and $25 \mathrm{sec})$, the solution was sonicated for $20 \mathrm{~min}$ until silver nitrate is fully dissolved (water color), adding several drops of the aqueous ammonia to form brownish fine precipitate of silver oxide, and then adding aqueous ammonia further to make the solution transparent due to formation of $\mathrm{Ag}\left(\mathrm{NH}_{3}\right)_{2}{ }^{+}$complex.

The second step was the sample of $\mathrm{AgNPs} / \mathrm{TiO}_{2}$ immersed into a reducing agent solution, which was Formaldehyde, then obtained $\mathrm{AgNPs} / \mathrm{TiO}_{2}$ sample was washed also washed with immersion in water.

In order to reach rates fixed by weight of doping noble metal (silver) on the layer of titania nanotubes i.e. values that we adopt in this paper, namely, $(0.3,0.5,0.7,0.9$ and $1.1 \mathrm{wt}$. $\%$, we did more experience and solutions to the way deposition electroless metal (silver) and examined by (EDX) to determine the proportion of metal doping, and we got the conditions that lead to get these percentages of doping metals.

\subsection{Physical characterization}

For the structural and morphological characterization of the anodized samples, top views were recorded by scanning electron microscopy (FESEM) using JEOL JSM-6510LVF FEG-SEM, (USA), and (AFM) study carried out by (AA3000, Angstrom Advanced Inc. USA). The crystallographic structures of the samples were determined using Ultima IV X-ray diffractometer of $1.5406 \AA$ from $\mathrm{Cu}$ k $\alpha$ (supplied by Rigaku Co.), USA.

Then the hydrogen sensing measurements were carried out using aluminum as electrodes in the temperature range of $25-150^{\circ} \mathrm{C}$. The sensing element was placed in a flow type homemade chamber. A Keithley 6517A Electrometer/High Resistance Meter was used to test the resistance variation of the nanotube sensor in alternating atmospheres of air and dilute $\mathrm{H}_{2}(50,100,500,1000 \mathrm{ppm})$. During the measurements, the temperature of the sensor was controlled with a Lakeshore 340 temperature controller.

\section{Results and Discussions}

\subsection{Synthesis of titania nanotubes}

The mechanism of $\mathrm{TiO}_{2}$ nanotube formation in fluorine-ion based electrolytes is said to occur as a result of three simultaneous processes: the field assisted oxidation of $\mathrm{Ti}$ metal to form titanium dioxide (Eqn.1) ${ }^{[21,22]}$, the field assisted dissolution of $\mathrm{Ti}$ metal ions in the electrolyte (Eqn.2) $)^{[21,22]}$, and the chemical dissolution of $\mathrm{Ti}$ and $\mathrm{TiO}_{2}$ due to etching by fluoride ions (Eqn.3) ${ }^{[21,22]}$, which is enhanced by the presence of $\mathrm{H}^{+}$ions ${ }^{[22]}$. $\mathrm{TiO}_{2}$ nanotubes are not formed on the pure $\mathrm{Ti}$ surface but on the thin $\mathrm{TiO}_{2}$ oxide layer naturally present on the $\mathrm{Ti}$ surface. Therefore, the 


\section{International Journal of Science and Research (IJSR) \\ ISSN (Online): 2319-7064 \\ Index Copernicus Value (2013): 6.14 | Impact Factor (2014): 5.611}

mechanism of $\mathrm{TiO}_{2}$ nanotubes formation is related to oxidation and dissolution kinetics. Schematic diagram of the formation of $\mathrm{TiO}_{2}$ nanotubes by anodization process is shown in figure (2) ${ }^{[21]}$. For a description of the process displayed in figure (2), the anodization mechanism for creating the nanotube structure is as follows:

a) Before anodization, a nano scale $\mathrm{TiO}_{2}$ passivation layer is on the Ti surface.

b) When constant voltage is applied, a pit is formed on the $\mathrm{TiO}_{2}$ layer.

c) As anodization time increases, the pit grows longer and larger, and then it becomes a nanopore. d) Nanopores and small pits undergo continuous barrier layer formation. (e) After specific anodization time, completely developed nanotubes are formed on the $\mathrm{Ti}$ surface.

$$
\begin{aligned}
& \mathrm{Ti}+2 \mathrm{H}_{2} \rightarrow \mathrm{TiO}_{2}+2 \mathrm{H}_{2} \\
& \mathrm{TiO}_{2}+6 \mathrm{~F}^{-}+4 \mathrm{H}^{+} \rightarrow \mathrm{TiF}_{6}^{2-}+2 \mathrm{H}_{2} \ldots \\
& \mathrm{Ti}^{4+}+6 \mathrm{~F}^{-} \rightarrow \mathrm{TiF}_{6}^{2-}
\end{aligned}
$$

In general the current density starts at a high magnitude then it reduces gradually with time then became nearly constant (steady state). (a)

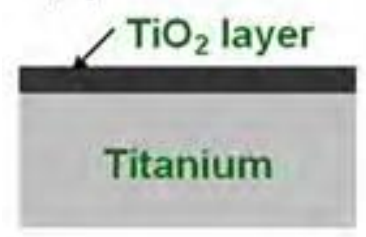

(d)

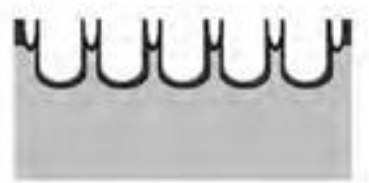

(b)

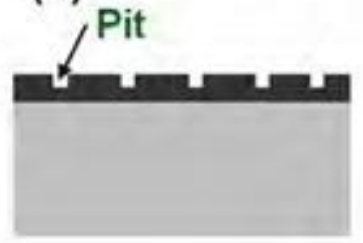

(c)

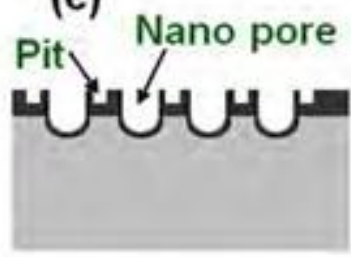

(e) $\mathrm{TiO}_{2}$ Nanotube

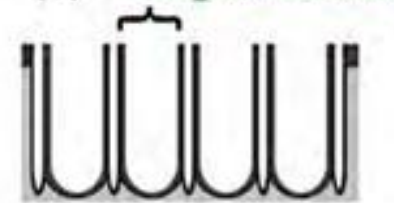

Figure 2: Schematic illustration of $\mathrm{TiO}_{2}$ nanotube formation ${ }^{\text {[21] }}$

FESEM examinations revealed that the nanotubes, with an average diameter of $\approx 74 \mathrm{~nm}$ and a height of $\approx 3.2 \mu \mathrm{m}$, figures (3a-f) shows FESEM images with different magnifications of typical $\mathrm{TiO}_{2}$ nanotube layers covered with $\mathrm{Ag}$ nanoparticles at different doping ratios $(0.0,0.3,0.5,0.7$, 0.9 and 1.1 wt.\%), respectively. The electroless-deposited $\mathrm{Ag}$ formed nanoparticles, the nucleation of the Ag takes place randomly on the surface of the nanotubes which diameter varies from 17 to $34 \mathrm{~nm}$, which changes with the doping ratios, also we observed of the silver nanoparticles are located at the top edges of the nanotubes, on their side walls and on the exterior mouth of the $\mathrm{TiO}_{2}$ nanotubes. $\mathrm{TiO}_{2}$ nanotubes covered with $\mathrm{Ag}$ nanoparticles with increasing of doping ratios exhibit quite a different morphology. The Ag particles are agglomerated and in the form of rings at the top of the nanotubes. The amount of $\mathrm{Ag}$ is here so high, that it results in a visible reduction of their internal diameter of titania nanotubes, as shown Table (1).

Table 1: The average diameter, inner diameter, wall thickness and grain size of un-doped $\mathrm{TiO}_{2}$ nanotubes and AgNPs $/ \mathrm{TiO}_{2}$ nanotubes at different doping ratios

\begin{tabular}{|c|c|c|c|c|}
\hline Sample & $\begin{array}{c}\text { Diameter } \\
(\mathrm{nm})\end{array}$ & $\begin{array}{c}\text { Inner } \\
\text { diameter } \\
(\mathrm{nm})\end{array}$ & $\begin{array}{c}\text { Wall } \\
\text { thickness } \\
(\mathrm{nm})\end{array}$ & $\begin{array}{c}\text { G. Size of } \\
\mathrm{Ag}(\mathrm{nm})\end{array}$ \\
\hline
\end{tabular}

\begin{tabular}{|c|c|c|c|c|}
\hline Un-doped & 74 & 63 & 11 & $==$ \\
\hline $\mathrm{AgNPs} / \mathrm{TiO}_{2}$ at 0.3 wt. $\%$ & 78 & 60 & 18 & 17 \\
\hline $\mathrm{AgNPs} / \mathrm{TiO}_{2}$ at 0.5 wt. $\%$ & 84 & 56 & 28 & 21 \\
\hline $\mathrm{AgNPs} / \mathrm{TiO}_{2}$ at 0.7 wt. $\%$ & 87 & 48 & 39 & 23 \\
\hline $\mathrm{AgNPs} / \mathrm{TiO}_{2}$ at 0.9 wt. $\%$ & 91 & 46 & 45 & 29 \\
\hline $\mathrm{AgNPs} / \mathrm{TiO}_{2}$ at 1.1 wt. $\%$ & 95 & 32 & 63 & 34 \\
\hline
\end{tabular}

At the doping ratios (0.9 and $1.1 \mathrm{wt} . \%)$, Ag nanoparticles are formed due to a further merge of the nanoparticles until having diameters as big as $150 \mathrm{~nm}$. We can be explained the following growth mechanism to explain the difference between the AgNPs diameter at the tube inner surface and those (AgNPs) at the top of the substrate. At the beginning of the electrodeposition process, the solution containing $\mathrm{Ag}^{+}$ species can reach all the surfaces exposed by the titania nanotubes sample. Once the Ag nanoparticles are formed and decorate the inner surface of the nanotubes, they grow inwards the nanotubes center, thus blocking at a certain point the further access for the Ag precursor solution into the nanotubes lumen. Thus, only the top of the sample is further accessible for the precursor solution resulting in a covering of $\mathrm{Ag}$ nanoparticles, this result is in agreement with the previous work ${ }^{[24]}$. 


\section{International Journal of Science and Research (IJSR) \\ ISSN (Online): 2319-7064 \\ Index Copernicus Value (2013): 6.14 | Impact Factor (2014): 5.611}

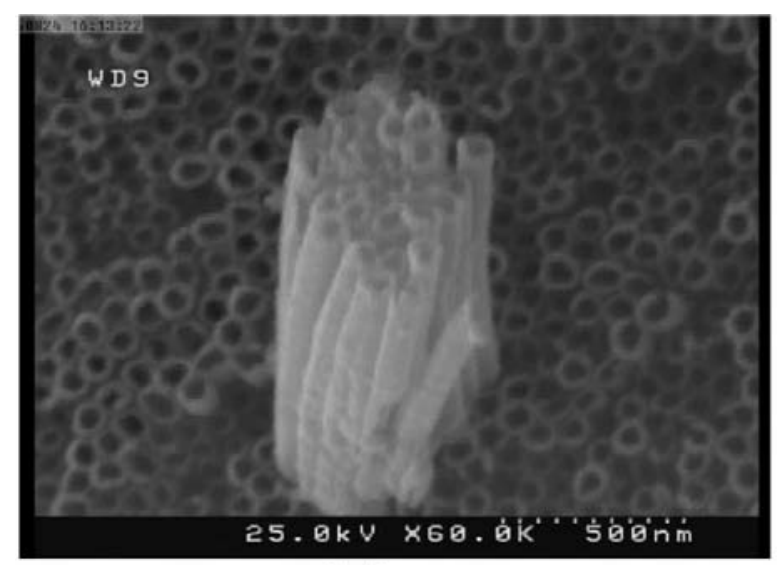

(a)

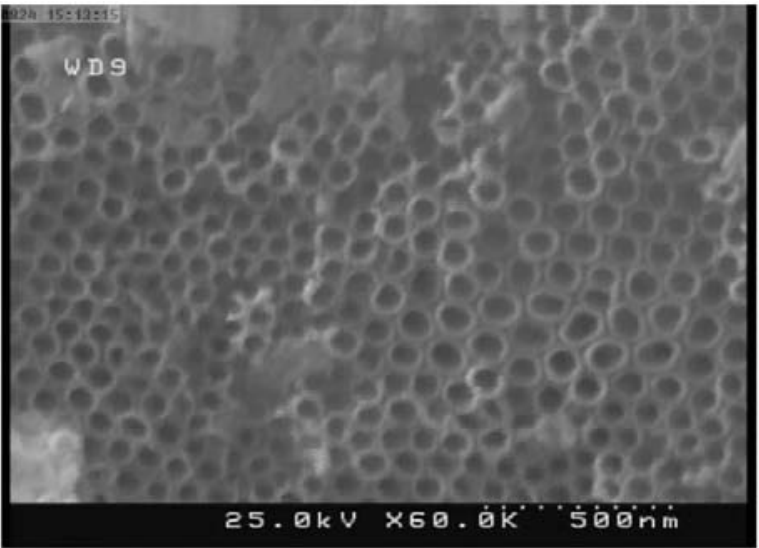

(c)

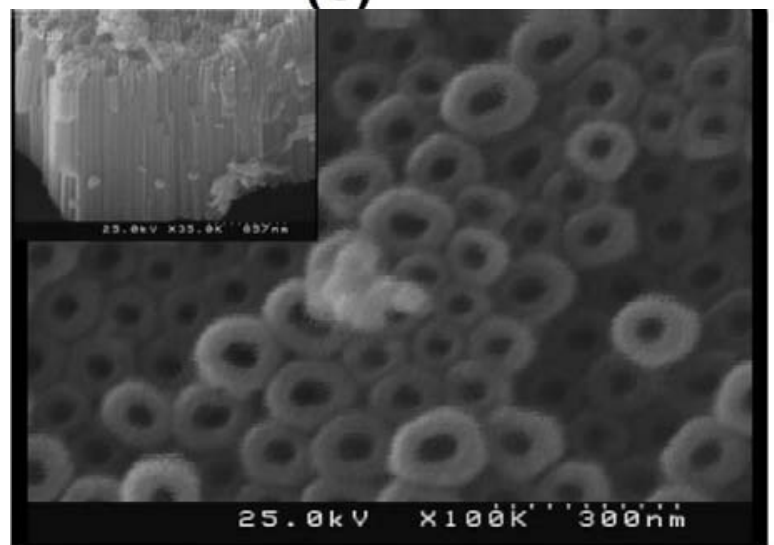

(e)

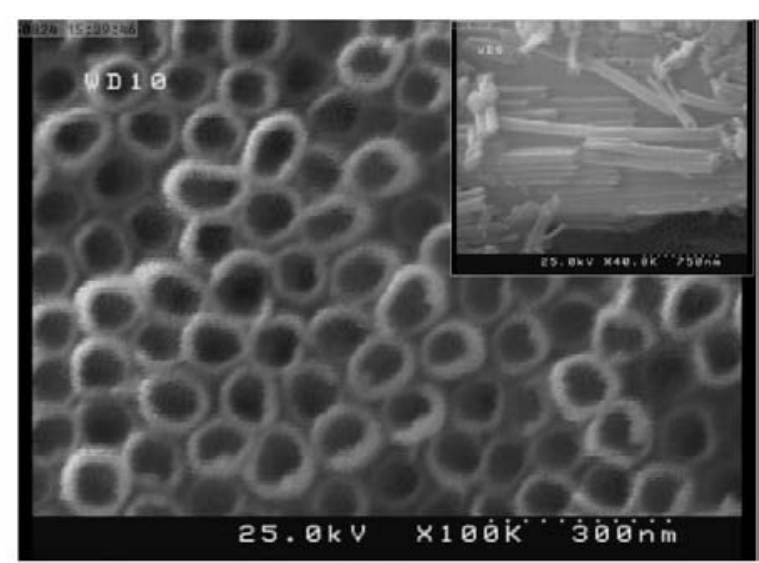

(b)

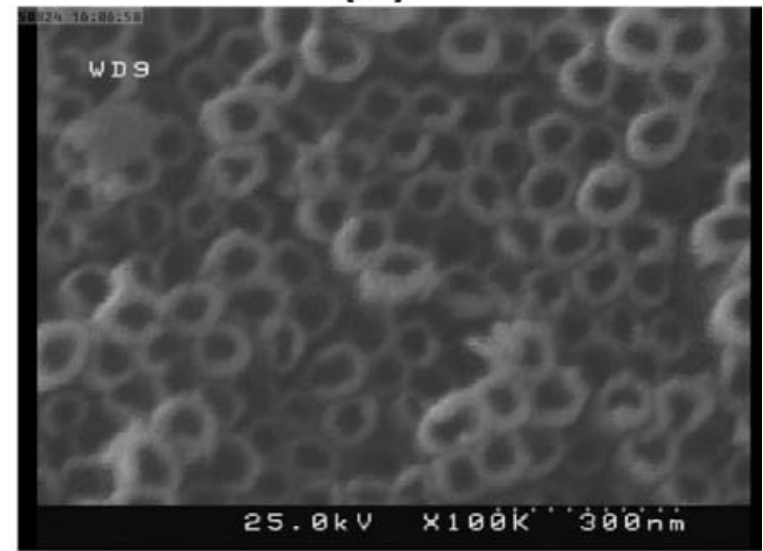

(d)

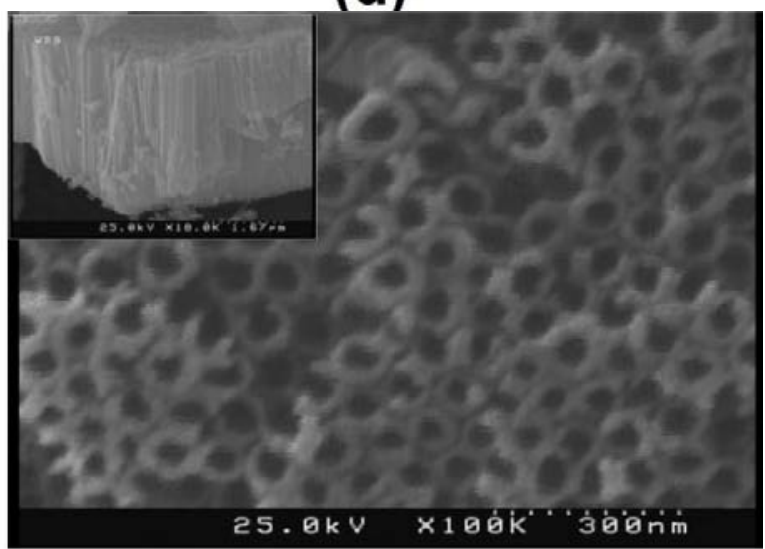

(f)

Figure 3: FESEM images of (a) un-doped $\mathrm{TiO}_{2}$ nanotubes, (b) $\mathrm{AgNPs} / \mathrm{TiO}_{2}$ nanotubes (top view) and (Insert of cross section) at 0.3 wt. $\%$, (c) $\mathrm{AgNPs} / \mathrm{TiO}_{2}$ nanotubes at 0.5 wt. $\%$, (d) $\mathrm{AgNPs} / \mathrm{TiO}_{2}$ nanotubes at $0.7 \mathrm{wt} . \%$, (e) $\mathrm{AgNPs} / \mathrm{TiO}{ }_{2}$ nanotubes (top view) and (Insert of cross section) at 0.9 wt.\%, (f) $\mathrm{AgNPs} / \mathrm{TiO}_{2}$ nanotubes (top view) and (Insert of cross section) at $1.1 \mathrm{wt} . \%$.

AFM analysis of the un-doped $\mathrm{TiO}_{2}$ nanotubes and doped $\mathrm{AgNPs} / \mathrm{TiO}_{2}$ nanotubes at different doping ratios $(0.0,0.3$, $0.5,0.7,0.9$ and $1.1 \mathrm{wt} \%$ ), are shown in figure (4a-f) respectively in $2 \mathrm{D}$ and $3 \mathrm{D}$ dimensional AFM images. The surface morphology of the $\mathrm{TiO}_{2}$ nanotubes and doped AgNPs $/ \mathrm{TiO}_{2}$ nanotubes changes with the different doping ratios, as observed from the AFM micrographs figures (4) left pictures proves that the grains are semiuniformly distributed within the scanning areas, with individual columnar grains extending upwards. The bright yellow color represents the wall of tubes with palladium nanoparticles while darker yellow represents pores. The tilted image reveals doped grains heights of a few tens of nanometers.
Despite the fact that the layers were deposited from the aggregation of nanoparticles, the morphologies of obtained films are rather satisfactory. All the deposited layers are quite uniform and their root mean square roughnesses vary. Film from un-doped $\mathrm{TiO}_{2}$ exhibits a slightly higher roughness, which can be due to stronger aggregation of the nanoparticles comparing to the doped ones.

The roughness of the doped surface is an important parameter, where the surface roughness not only describes the light scattering but also gives an idea about the quality of the surface under investigation, in addition to providing some insight on the growth morphology and the increase in 


\section{International Journal of Science and Research (IJSR) \\ ISSN (Online): 2319-7064 \\ Index Copernicus Value (2013): 6.14 | Impact Factor (2014): 5.611}

surface roughness of the films leads to a increase in the efficiency for sensing properties, therefore, it is very important to investigate the surface morphology of the films.

The values of the root mean square (RMS), surface roughness of $\mathrm{TiO}_{2}$ nanotubes and grain size of doped $\mathrm{AgNPs} / \mathrm{TiO}_{2}$ nanotubes are shown in the Table (2), i.e. the root mean square (RMS) and surface roughness increased with increasing the doping ratios of $\mathrm{Ag}$ nanoparticles due the presence of the fine dispersed phase, this result is in agreement with the previous work ${ }^{[25]}$.

In general, as the doping ratios of $\mathrm{Ag}$ nanoparticles increases on titania layer, the RMS and roughness of the AgNPs/ $\mathrm{TiO}_{2}$ nanotubes and the grain size increase.

(a)

(2D)

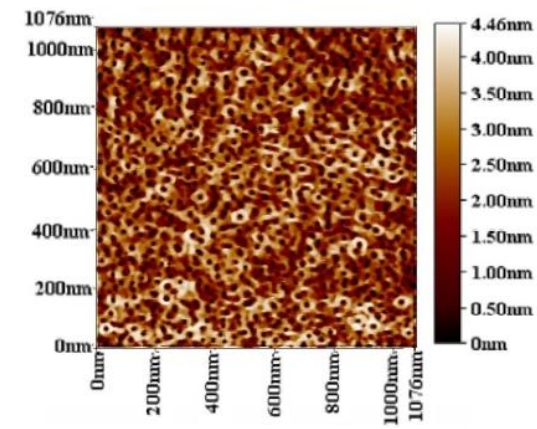

(3D)

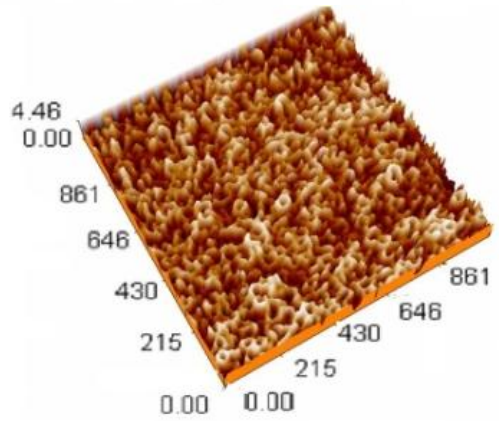

(d)

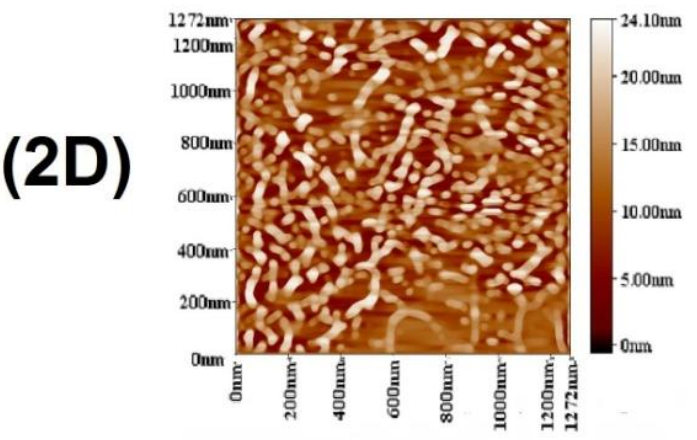

Table 3: Morphological characteristics from AFM images for $\mathrm{TiO}_{2}$ nanotubes and doped $\mathrm{AgNPs} / \mathrm{TiO}_{2}$ nanotubes

\begin{tabular}{|c|c|c|c|}
\hline Sample & $\begin{array}{c}\text { Grain size } \\
\text { of } \mathrm{Ag} \\
\text { (nm) }\end{array}$ & $\begin{array}{c}\text { Roughness } \\
\text { average } \\
\text { (nm) }\end{array}$ & $\begin{array}{c}\text { Root mean } \\
\text { square } \\
\text { (RMS) }(\mathrm{nm})\end{array}$ \\
\hline $\mathrm{Un}-\mathrm{doped} \mathrm{TiO}_{2}$ & $==$ & 2.3 & 3.03 \\
\hline $\mathrm{AgNPs} / \mathrm{TiO}_{2}$ at $0.3 \mathrm{wt.} \%$ & 23.83 & 3.7 & 4.84 \\
\hline $\mathrm{AgNPs} / \mathrm{TiO}_{2}$ at $0.5 \mathrm{wt} \%$ & 31.31 & 4.13 & 6.85 \\
\hline $\mathrm{AgNPs} / \mathrm{TiO}_{2}$ at 0.7 wt.\% & 38.48 & 5.89 & 2.13 \\
\hline $\mathrm{AgNPs} / \mathrm{TiO}_{2}$ at 0.9 wt.\% & 43.97 & 7.81 & 9.92 \\
\hline $\mathrm{AgNPs} / \mathrm{TiO}_{2}$ at $1.1 \mathrm{wt.} \%$ & 34.78 & 13.1 & 15 \\
\hline
\end{tabular}

(b)

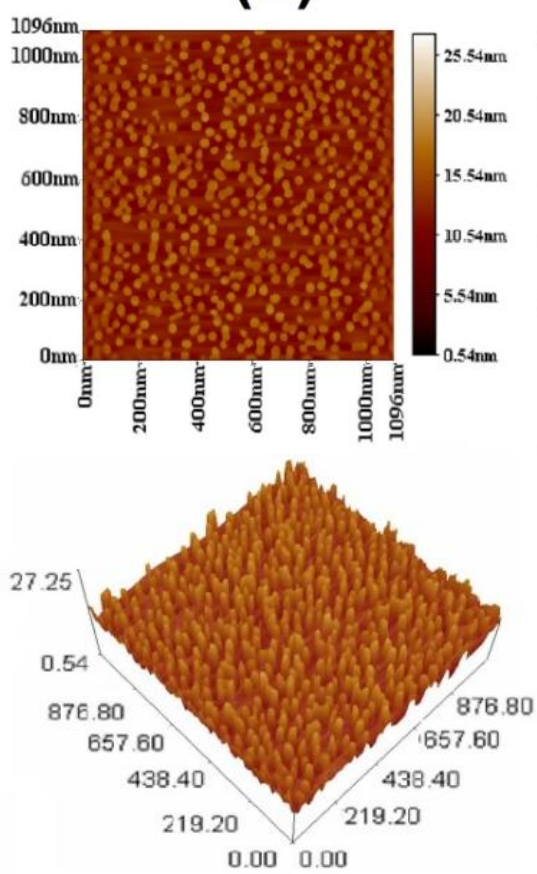

(e)

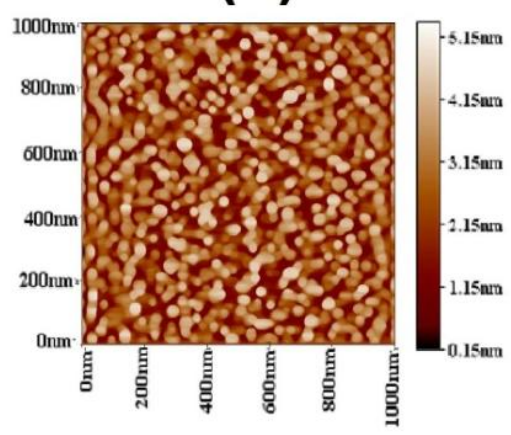

(c)
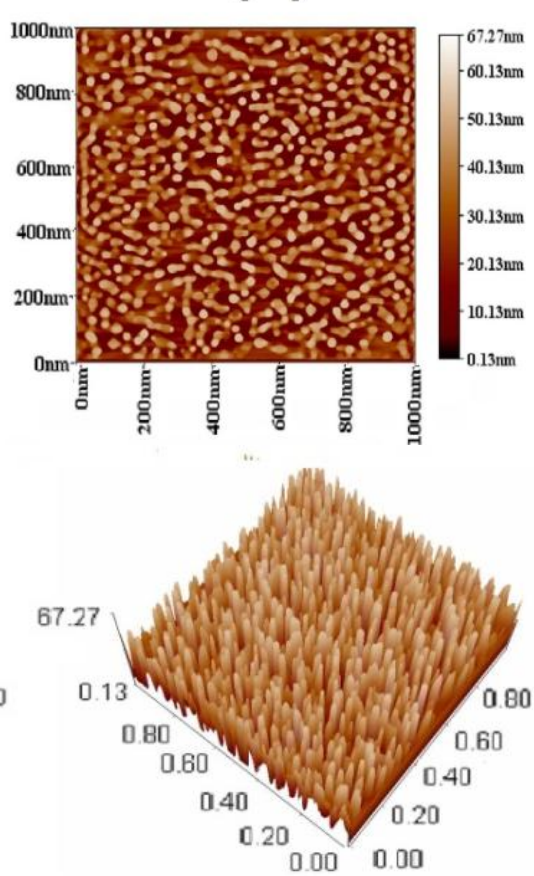

(f)

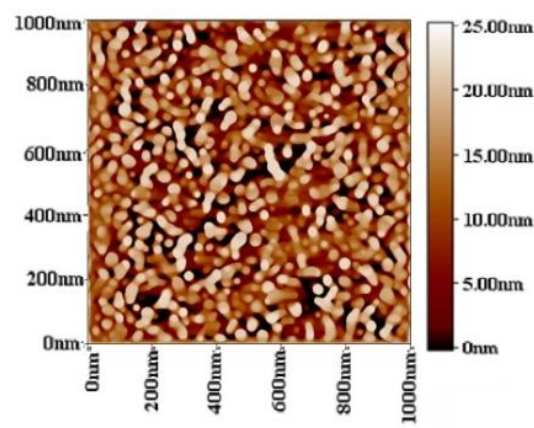



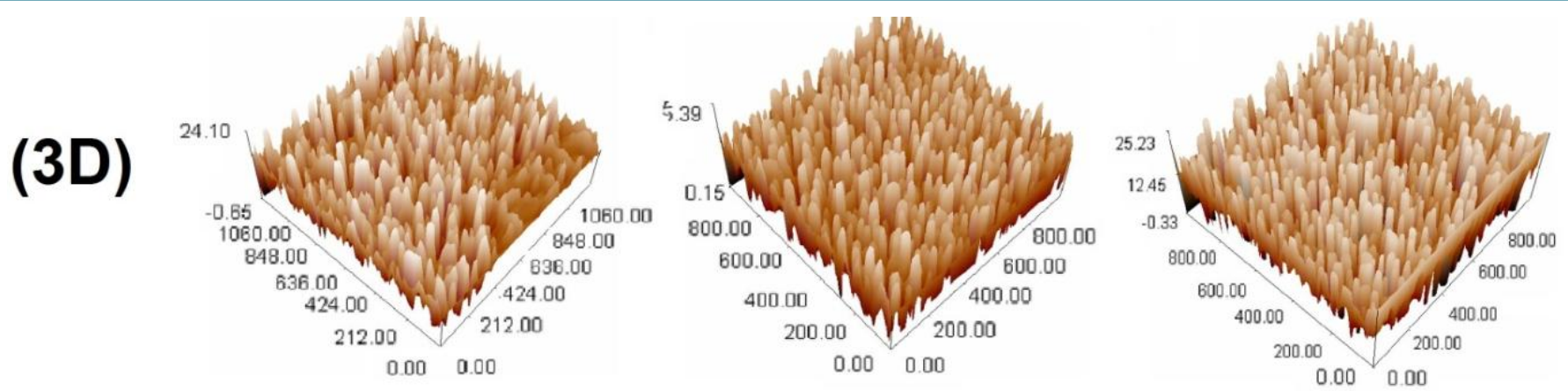

Figure 4: $2 \mathrm{D}$ and $3 \mathrm{D}$ AFM images of (a) $\mathrm{TiO}_{2}$ nanotubes, (b) $\mathrm{AgNPs} / \mathrm{TiO}_{2}$ nanotubes at $0.3 \mathrm{wt} . \%$, (c) $\mathrm{AgNPs} / \mathrm{TiO}_{2}$ nanotubes at 0.5 wt.\%, (d) $\mathrm{AgNPs} / \mathrm{TiO}_{2}$ nanotubes at 0.7 wt.\%, (e) $\mathrm{AgNPs} / \mathrm{TiO}_{2}$ nanotubes at 0.9 wt.\%, (f) $\mathrm{AgNPs} / \mathrm{TiO}_{2}$ nanotubes at 1.1 wt.\%.

EDX analysis for elemental composition of un-doped titania and silver doped titania was done, as shown in figure (5) and Table (3). The high weight $\%$ of titanium and oxygen shows that they are the main components. The weight $\%$ loading of the dopant in $\mathrm{Ag}-\mathrm{TiO}_{2}$ at 0.3 wt. $\%$ was much higher compared to that of $\mathrm{Ag}-\mathrm{TiO}_{2}$ at 0.5 wt. $\%$ and this can be suggested to be due to silver dopant attaching onto the surface of titania and not incorporated into the crystal lattice in which case it would be shadowed from detection, this result is in agreement with the previous work ${ }^{[26,27,28]}$.
Table 3: Energy dispersive X-ray spectroscopy results of un-doped $\mathrm{TiO}_{2}$ nanotubes and $\mathrm{AgNPs} / \mathrm{TiO}_{2}$ doped at different doping ratios

\begin{tabular}{|c|c|c|c|}
\hline Sample & $\begin{array}{c}\text { Titanium } \\
(\mathrm{Ti}) \\
w \%\end{array}$ & $\begin{array}{c}\text { Oxygen } \\
(\mathrm{O}) \\
w \%\end{array}$ & $\begin{array}{c}\text { Dopant } \\
(\mathrm{Ag}) \\
\text { wt\% }\end{array}$ \\
\hline $\mathrm{Un}-\mathrm{doped} \mathrm{TiO}_{2}$ & 74.4 & 25.6 & 0 \\
\hline $\mathrm{AgNPs} / \mathrm{TiO}_{2}$ at 0.3 wt.\% & 73.8 & 25.9 & 0.3 \\
\hline $\mathrm{AgNPs} / \mathrm{TiO}_{2}$ at 0.5 wt.\% & 75.4 & 24.1 & 0.5 \\
\hline $\mathrm{AgNPs} / \mathrm{TiO}_{2}$ at 0.7 wt.\% & 73.7 & 25.6 & 0.7 \\
\hline $\mathrm{AgNPs} / \mathrm{TiO}_{2}$ at 0.9 wt.\% & 74.6 & 24.5 & 0.9 \\
\hline $\mathrm{AgNPs} / \mathrm{TiO}_{2}$ at 1.1 wt.\% & 73.4 & 24.7 & 0.11 \\
\hline
\end{tabular}

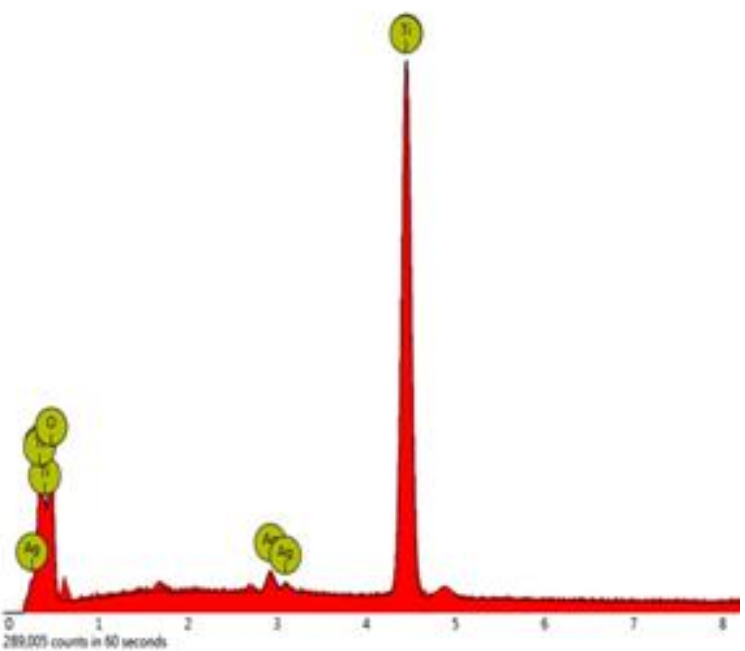

Figure 5: EDX analysis of (a) un-doped $\mathrm{TiO}_{2}$ nanotubes, (b) $\mathrm{AgNPs} / \mathrm{TiO}_{2}$ nanotubes at 0.9 wt. \%

Throughout studying the X-ray diffraction spectrum, we can understand the crystalline growth nature of $\mathrm{TiO}_{2}$ nanotubes prepared by anodization method and $\mathrm{Ag}$ nanoparticles deposition on $\mathrm{TiO}_{2}$ nanotubes layers by electroless method at different doping ratios $(0.0,0.3,0.5,0.7,0.9$ and 1.1 wt.\%).

The phase composition and crystallite sizes of the synthesized titania nanotubes were determined by XRD analysis. The XRD patterns of $\mathrm{TiO}_{2}$ nanotubes and AgNPs $/ \mathrm{TiO}_{2}$ nanotubes are shown in figure (6). The wideangles XRD pattern showed anatase-phase $\mathrm{TiO}_{2}$ with characteristic diffraction peaks of $2 \theta$ values. Thus the prepared $\mathrm{TiO}_{2}$ nanotubes (pattern a) and $\mathrm{AgNPs} / \mathrm{TiO}_{2}$ nanotubes (pattern b-f) nanotubes were well-crystallized pure anatase form, this means predominating the anatase phase.

This can be seen when increasing the doping ratio leads to increased (FWHM) of anatase peaks.

From the peaks it can be concluded that change in the doping ratio lead to increased concentration of $\mathrm{Ag}$ nanoparticles on the surface layer of titania nanotubes and thus increase the fill of titania nanotubes with $\mathrm{Ag}$ nanoparticles. The increased doping ratio might have to the increased potential energy of atomic diffusion barrier and grain growth, this result is in agreement with the previous work $[26,29,30]$. 


\section{International Journal of Science and Research (IJSR) \\ ISSN (Online): 2319-7064}

Index Copernicus Value (2013): 6.14 | Impact Factor (2014): 5.611

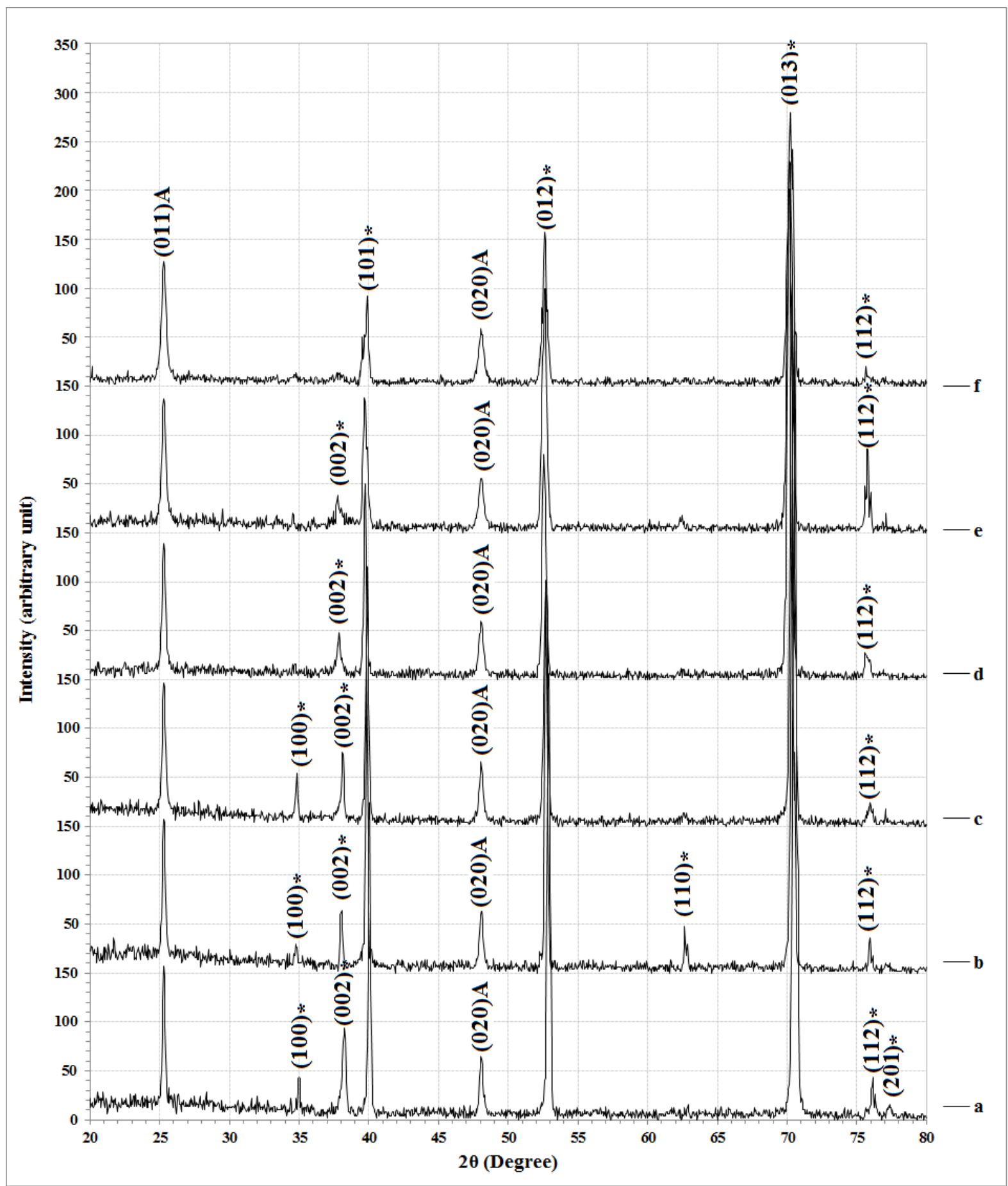

Figure 6: XRD patterns of (a) un-doped $\mathrm{TiO}_{2}$ nanotubes, (b) $\mathrm{AgNPs} / \mathrm{TiO}_{2}$ nanotubes at 0.3 wt. $\%$, (c) $\mathrm{AgNPs} / \mathrm{TiO}$ nanotubes at 0.5 wt.\%, (d) $\mathrm{AgNPs} / \mathrm{TiO}_{2}$ nanotubes at 0.7 wt.\%, (e) $\mathrm{AgNPs} / \mathrm{TiO}_{2}$ nanotubes at 0.9 wt. $\%$, (f) $\mathrm{AgNPs} / \mathrm{TiO}_{2}$ nanotubes at 1.1 wt. $\%$

\subsection{Hydrogen sensing properties}

Fabricated AgNPs-doped $\mathrm{TiO}_{2}$ nanotubes were converted into the gas sensor device. Finally, these devices were placed to gas sensor testing cell.

The gas sensing measurements of $\mathrm{AgNPs} / \mathrm{TiO}_{2}$ samples were carried out by measuring the resistance across two electrodes for different temperatures and $\mathrm{H}_{2}$ concentrations. The sensor response was calculated by following equation ${ }^{[31]}$ :

$$
S=\frac{R_{a}}{R_{g}}
$$

where $R a$ is the resistance in dry air, and $R g$ is the resistance under a reducing gas. The response time, Tres is defined as the time required to reach $90 \%$ of the steady response signal. The recovery times, Trec denotes the time needed to recover $90 \%$ of the original baseline resistance ${ }^{[32]}$.

The hydrogen sensing measurements are carried out using aluminum as electrodes in a temperature range $25-300^{\circ} \mathrm{C}$. The sensing element was placed in a flow type homemade chamber. A constant bias voltage of $6 \mathrm{~V}$ is applied to the $\mathrm{AgNPs} / \mathrm{TiO}_{2}$ nanotube sensor device, and the change in the

\section{Volume 5 Issue 2, February 2016}




\section{International Journal of Science and Research (IJSR) \\ ISSN (Online): 2319-7064}

Index Copernicus Value (2013): 6.14 | Impact Factor (2014): 5.611

DC resistivity is measured upon exposure to $(15,30,45,60$, $75 \mathrm{ppm}) \mathrm{H}_{2}$ in atmosphere at different temperatures. The resistivity values versus time for the $\mathrm{AgNPs} / \mathrm{TiO}_{2}$ nanotube sensor at various temperatures. To establish the baseline, the resistivity is measured under atmosphere flow. Then the $\mathrm{AgNPs} / \mathrm{TiO}_{2}$ nanotube sensor is exposed to the desired concentration of $\mathrm{H}_{2}$ for $100 \mathrm{sec}$ at room temperature. The exposing and purging times are $43 \mathrm{sec}$ at $100^{\circ} \mathrm{C}$.

The $\mathrm{H}_{2}$ sensing mechanism of $\mathrm{TiO}_{2}$ nanotubes is explained by a variety of factors. The primary factor in the interaction between the nanotubes and hydrogen is the chemisorption of the dissociated hydrogen on the $\mathrm{TiO}_{2}$ surface ${ }^{[32]}$. The electrical conductivity of $\mathrm{TiO}_{2}$ nanotubes is enhanced when the chemisorbed hydrogen acts in the surface states of the nanotubes. The chemisorption of hydrogen onto the walls and intertubular connecting points could cause easy charge transfer with less resistance in tube to tube transfers. Another factor is that the platinum electrode pads may play a role in the hydrogen absorption. It is well known that platinum is a catalyst for hydrogen. Thus, hydrogen can dissociate on platinum surfaces. These dissociated hydrogen atoms may spill onto the nanotube surface, where they diffuse into the nanotube surface ${ }^{[33]}$. Another factor is that anatase, the polymorph of $\mathrm{TiO}_{2}$, has been reported to be of high sensitivity toward reducing gases like hydrogen and carbon monoxide ${ }^{[34]}$. The hydrogen diffused to the interstitial sites of $\mathrm{TiO}_{2}$.

In this study, the gas sensing properties of un-doped $\mathrm{TiO}_{2}$ and AgNPs-doped $\mathrm{TiO}_{2}$ sensing films are characterized in terms of response, response time and recovery time as a function of operating temperature, gas concentration and $\mathrm{Ag}$ loading.

The sensitivity and response time of the thin films of undoped $\mathrm{TiO}_{2}$ and AgNPs-doped $\mathrm{TiO}_{2}$ nanoparticles at different concentrations $(0.3,0.5,0.7,0.9$ wt.\%) of $\mathrm{Ag}$ nanoparticles as a function of $\mathrm{H}_{2}$ concentration between (15, $30,45,60,85 \mathrm{ppm})$ of concentration at temperature range $\left(25-350^{\circ} \mathrm{C}\right)$ are shown in Figure (5). The sensitivity increased considerably by AgNPs-doped $\mathrm{TiO}_{2}$ nanotubes [show in Figures (5a-f)]. Therefore, doping the $\mathrm{TiO}_{2}$ nanoparticles with $0.9 \mathrm{Wt} . \% \mathrm{Ag}$ sensor at $300^{\circ} \mathrm{C}$ had better sensitivity. In Figure (5) it can be seen that the sensitivity increased considerably by AgNPs-doped $\mathrm{TiO}_{2}$ nanotubes with 0.9 wt.\% Ag. The sensitivity of 79 and response time of $45 \mathrm{sec}$ were obtained at $75 \mathrm{ppm}$ of $\mathrm{H}_{2}$ concentration for the AgNPs-doped $\mathrm{TiO}_{2}$ nanotubes with 0.9 wt.\% Ag.

Thus, in this study 0.9 wt.\% $\mathrm{AgNPs} / \mathrm{TiO}_{2}$ showed good sensitivity for $\mathrm{H}_{2}$ gas as compared to the other literatures. The gas-sensing sensitivity, $\mathrm{S}$ is defined as the ratio $\mathrm{Ra} / \mathrm{Rg}$, where $\mathrm{Ra}$ is the resistance in dry air, and $\mathrm{Rg}$ is the resistance in test gas. The response time, Tres is defined as the time required until $90 \%$ of the response signal is reached. The recovery times, Trec denotes the time needed until $90 \%$ of the original baseline signal is recovered.

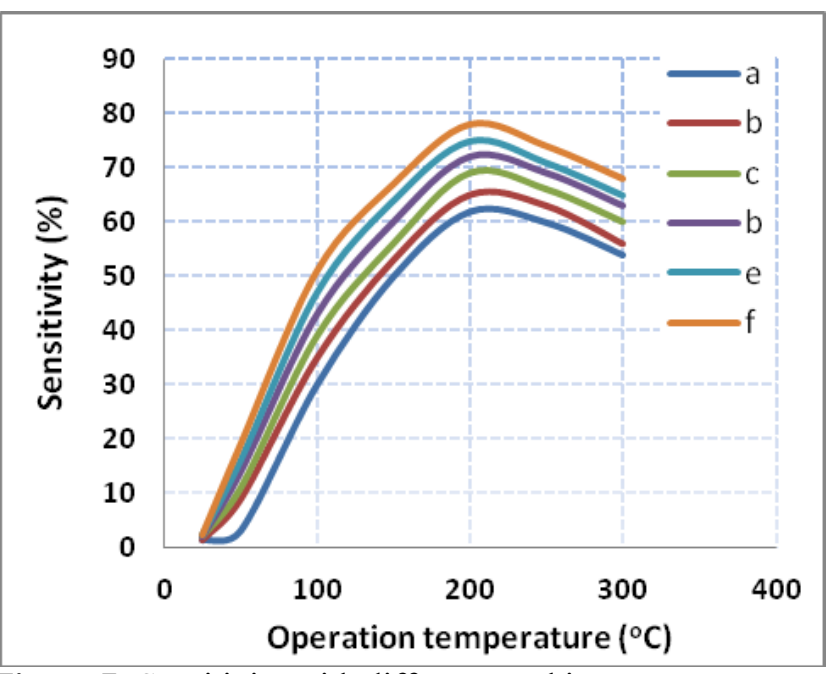

Figure 7: Sensitivity with different working temperatures at 75ppm of the(a) un-doped $\mathrm{TiO}_{2}$ nanotubes, (b) $\mathrm{AgNPs} / \mathrm{TiO}_{2}$ nanotubes at $0.3 \mathrm{wt} . \%$, (c) $\mathrm{AgNPs} / \mathrm{TiO}_{2}$ nanotubes at 0.5 wt.\%, (d) AgNPs $/ \mathrm{TiO}_{2}$ nanotubes at 0.7 wt. \%, (e)

$\mathrm{AgNPs} / \mathrm{TiO}_{2}$ nanotubes at 0.9 wt. $\%$, (f) $\mathrm{AgNPs} / \mathrm{TiO}_{2}$ nanotubes at $1.1 \mathrm{wt} . \%$

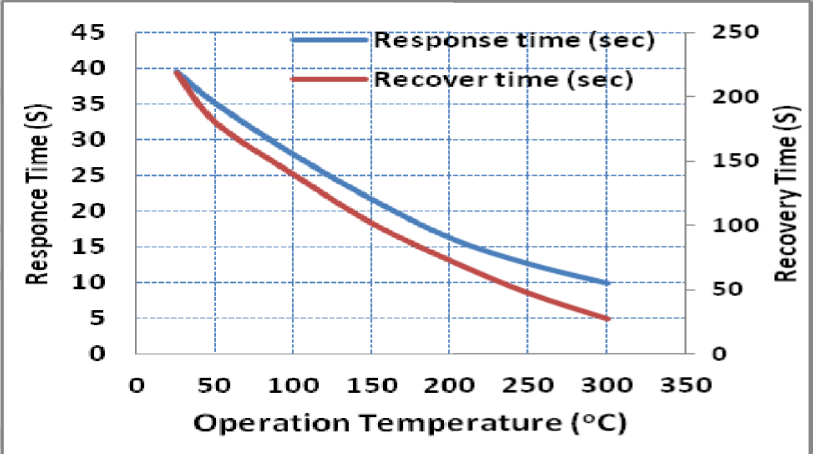

Figure 8: Response time of the $\mathrm{AgNPs} / \mathrm{TiO}_{2}$ with concentration $(0.9 \mathrm{wt} . \%)$ at different working temperatures

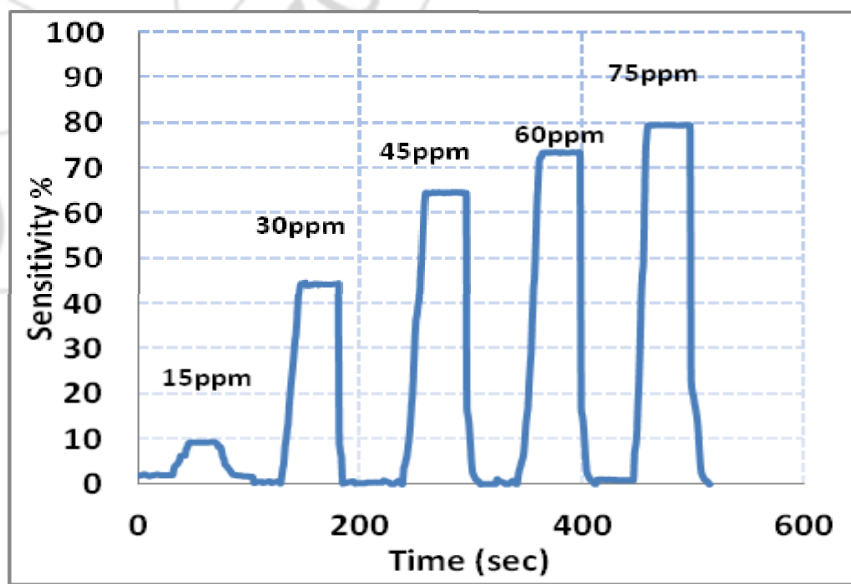

Figure 9: Sensitivity behavior of $\mathrm{AgNPs} / \mathrm{TiO}_{2}$ thin film at $(0.9$ wt. $\%)$ to different hydrogen concentrations. The bias voltage was $6 \mathrm{v}$ with the temperature set to $200^{\circ} \mathrm{C}$

\section{Conclusions}

Titania nanotubes films were successfully prepared by a electrochemical anodization process. Special efforts were made to enhance the porosity of $\mathrm{TiO}_{2}$ nanotubes films. In addition silver deposition on titania nanotubes layer using 


\section{International Journal of Science and Research (IJSR) ISSN (Online): 2319-7064 \\ Index Copernicus Value (2013): 6.14 | Impact Factor (2014): 5.611}

electroless process at different concentrations of silver. The structural, morphological and sensing properties of prepared films were investigated as a function of film fabrication conditions, testing temperature and $\mathrm{H}_{2}$ concentration. The gas sensor sensitivity was temperature dependent and the highest sensitivity was observed at temperature $(250 \circ \mathrm{C})$ of $\mathrm{H}_{2}$ gas at $(0.9$ wt. $\%)$ of AgNPs doped on $\mathrm{TiO}_{2}$ nanotubes layer. It was found that the $\mathrm{AgNPs} / \mathrm{TiO}_{2}$ nanotubes films have several important sensor characteristics such as repeatability, high response, and fast response/recovery times to $\mathrm{H}_{2}$ gas. The overall recovery times of the sample were decreased by increasing the operating temperatures. It was also found that the doping of AgNPs and porosity of the film were two important parameters, which affect the main gas sensing characteristics of $\mathrm{TiO}_{2}$ based $\mathrm{H}_{2}$ sensors. The measurements revealed that the sensor response decreased by increasing the film thickness. The maximum sensitivity of $79 \%$ was measured at $250{ }^{\circ} \mathrm{C}$.

\section{Acknowledgements}

I would like to thank the assistant professor Dr Abdul Karim Mohammed Ali al-Samarrai in the Department of Chemistry, Faculty of Science, University of Baghdad, for his tips and great scientific ideas in the field of nanotechnology, and I would also like to thank assistant professor Dr. Fuad in the Physics Department, Faculty of Science, University of Baghdad, for his help in the gas sensor experiments.

\section{References}

[1] Bevenot X, Trouillet A, Veillas C, Gagnaire H, Clement M. Hydrogen leak detection using an optical fiber sensor for aerospace applications. Sensors and Actuators B: Chemical 2000;67:57-67.

[2] Yazdi N, Ayazi F, Najafi K. Micromachined inertial sensors. Proceedings of the IEEE 1998;86:1640-59.

[3] Katsuki A, Fukui K. H-2 selective gas sensor based on $\mathrm{SnO}_{2}$. Sensors and Actuators B: Chemical 1998;52:307.

[4] Boon-Bretta L, Bousek J, Moretto P. Reliability of commercially available hydrogen sensors for detection of hydrogen at critical concentrations: part II - selected sensor test results. International Journal of Hydrogen Energy 2009; 34:562-71.

[5] Aroutiounian V. Metal oxide hydrogen, oxygen, and carbon monoxide sensors for hydrogen setups and cells. International Journal of Hydrogen Energy 2007;32:1145-58.

[6] Miyazaki H, Hyodo T, Shimizu Y, Egashira M. Hydrogensensing properties of anodically oxidized $\mathrm{TiO}_{2}$ film sensors: effects of preparation and pretreatment conditions. Sensors and Actuators B: Chemical 2005;108:467-72.

[7] Varghese OK, Gong D, Paulose M, Ong KG, Grimes CA. Hydrogen sensing using titania nanotubes. Sensors and Actuators B: Chemical 2003;93:338-44.

[8] Gong D, Grimes CA, Varghese OK, Hu W, Singh RS, Chen $\mathrm{Z}$, et al. Titanium oxide nanotube arrays prepared by anodic oxidation. Journal of Materials Research 2001;16:3331-4.
[9] Mor GK, Varghese OK, Paulose M, Mukherjee N, Grimes CA. Fabrication of tapered, conical-shaped titania nanotubes. Journal of Materials Research 2003;18:2588-93.

[10]Cai Q, Paulose M, Varghese OK, Grimes CA. The effect of electrolyte composition on the fabrication of self-organized titanium oxide nanotube arrays by anodic oxidation. Journal of Materials Research 2005;20:230-6.

[11] Mor GK, Shankar K, Paulose M, Varghese OK, Grimes CA. Enhanced photocleavage of water using titania nanotube arrays. Nano Letters 2005;5:191-5.

[12]U. Diebold. "The Surface Science of Titanium Dioxide", Surf. Sci. Rep. 48 (2003) 53.

[13]Haidar Hameed Hamdan, Hareith I. Jaafar, Abdulalkareem M. A. Alsammerraei, "Study of the effect of $\mathrm{NH}_{4} \mathrm{~F}$ concentration on the structure of electrochemically prepared $\mathrm{TiO}_{2}$ nanotubes", Iraqi Journal of Science. Vol. 53.No 2.2012.Pp 827-831.

[14]Zuruzi et al: 'Metal Oxide "Nanosponges" as Chemical Sensors: Highly Sensitive Detection of Hydrogen with Nanoporous Titania' Angew. Chem. Int. Ed. vol. 46, 2007, pages 4298 - 4301

[15] Youn-Ki Juna, Hyun-Su Kima, Jong-Heun Leeb, Seong-Hyeon Hong " $\mathrm{CO}$ sensing performance in micro-arc oxidized $\mathrm{TiO}_{2}$ films for air quality control", Sensors and Actuators B: Chemical, Volume 120, Issue 1, 14 December 2006, Pages 69-73

[16]H. Tang, K. Prasad, R. Sanjinés, F. Lévy. " $\mathrm{TiO}_{2}$ anatase thin films as gas sensors", Sensors and Actuators B: Chemical Volume 26, Issues 1-3, 1995, Pages 71-75

[17]D. Mardarea, , , N. Iftimiea, b, D. Lucaa, " $\mathrm{TiO}_{2}$ thin films as sensing gas materials" , Journal of NonCrystalline Solids Volume 354, Issues 35-39, 1 October 2008, Pages 4396-4400.

[18] Maolin Zhang, Zhanheng Yuan, , Jianping Song, Cheng Zheng, "Improvement and mechanism for the fast response of a $\mathrm{Pt} / \mathrm{TiO}_{2}$ gas sensor " Sensors and Actuators B: Chemical, Volume 148, Issue 1, 30 June 2010, Pages 87-92.

[19] I Hayakawaa, , Y Iwamotoa, 1, K Kikutab, S Hiranob "Gas sensing properties of platinum dispersed- $\mathrm{TiO}_{2}$ thin film derived from precursor, Sensors and Actuators B: Chemical Volume 62, Issue 1, 25 January 2000, Pages 55-60.

[20] Mohammed A. Amin, Sahar A. Fadlallah, Ghaida S. Alosaimi, "In situ aqueous synthesis of silver nanoparticles supported on titanium as active electrocatalyst for the hydrogen evolution reaction", international journal o f hydrogen energy 39 (2014) 19519-19540.

[21] Mor G. K., Shankar K., Paulose M., Varghese O. K., Grimes C. A., (2006), "Use of highly-ordered $\mathrm{TiO}_{2}$ nanotube arrays in dye-sensitized solar cells", Nano Lett. 6, PP: 215-218.

[22] Haidar Hameed Hamdan, "Fabrication of $\mathrm{TiO}_{2}$ Nanotubes Using Electrochemical Anodization” M.Sc. thesis, College of Science, Baghdad University, (2012).

[23] Shankar K., Mor G.K., Fitzgerald A., and Grimes C., (2007), "Cation effect on the electrochemical formation of very high aspect ratio $\mathrm{TiO}_{2}$ nanotube arrays in formamide-water mixtures", J.Phys. Chem. C111, 21, (2007) 
[24]A. Roguska, M. Pisarek, A. Kudelski, M. Lewandowska, K.J. Kurzydłowski, and M. JanikCzachor, " Raman Investigations of AdsorbateSubstrate Interactions on Composite $\mathrm{Ag}$ (or $\mathrm{Cu}$ ) $/ \mathrm{TiO}_{2}$ Nanotubes/Ti Substrates", journal of Raman Spectroscopy Volume 40, Issue 11, pages 1652-1656, November 2009.

[25] Loganathan, K., Bommusamy, P., Muthaiahpillai, P., Velayutham, M. The Syntheses, Characterizations, and Photocatalytic Activities of Silver, Platinum, and Gold Doped $\mathrm{TiO}_{2}$ Nanoparticles Environmental Engineering Research 16 2011: pp. 81 - 90.

[26] Atsile Rosy Ocwelwang, Lilian Tichagwa, "Synthesis and Characterisation of $\mathrm{Ag}$ and Nitrogen Doped $\mathrm{TiO}_{2}$ Nanoparticles Supported on A Chitosan-Pvae Nanofibre Support", International Journal of Advanced Research in Chemical Science (IJARCS) Volume 1, Issue 2, April 2014, PP 28-37.

[27] Choi, J., Park, H., Hoffmann, M.R. . (2009). Effects of Single metal-ion doping on the visible light photoreactivity of $\mathrm{TiO}_{2}$. Journal of Physical Chemistry, C, 1755.

[28] Sobana, N., Muruganadham, M., Swaminathan, M. (2006). Nano-Ag particles doped $\mathrm{TiO}_{2}$ for efficient photodegradation of direct azo dyes. Journal of Molecular Catalysis A: Chemical , 258, 124-132.

[29] Nasr-Esfahani, M., Habibi, M.H. (2008). Silver Doped $\mathrm{TiO}_{2}$ Nanostructure Composite Photocatalyst Film Synthesized by Sol-Gel Spin and Dip Coating Technique on Glass. International Journal of Photoenergy, 628713, 1-11.

[30] Behnajady, M. M. (2008). Enhancement of photocatalytic activity of $\mathrm{TiO}_{2}$ nanoparticles by Silver doping: Photodeposition versus Liquid impregnation methods. Global NEST Journal, 10, 1, 1-7.

[31] Haidar Hameed Hamdan, Marwa Abdul Muhsien, Evan T. Salem, Ibrahim R. Agool, "Gas sensing of $\mathrm{Au} / \mathrm{n}-$ $\mathrm{SnO}_{2} / \mathrm{p}-\mathrm{PSi} / \mathrm{c}-\mathrm{Si}$ heterojunction devices prepared by rapid thermal oxidation", Applied Nanoscience August 2014, Volume 4, Issue 6, pp 719-732.

[32] Haidar Hameed. Hamdan, Seyed Ali Hoseini, Marwa Abdul Muhsien, "Palladium-Doped $\mathrm{SnO}_{2}$ Nanostructure Thin Film Prepared Using SnCl4 Precursor for Gas Sensor Application", Proceedings of the 4th International Conference on Nanostructures (ICNS4) 12-14 March, 2012, Kish Island, I.R. Iran.

[33] Raupp GB, Dumesic JA. Adsorption of $\mathrm{CO}, \mathrm{CO}_{2}, \mathrm{H}_{2}$ and $\mathrm{H}_{2} \mathrm{O}$ on titania surfaces with different oxidation states. Journal Physical Chemistry 1985;89:5240-6.

[34] Birkefeld LD, Azad AM, Akbar SA. Carbon monoxide and hydrogen detection by anatase modification of titanium dioxide. Journal of the American Ceramic Society 1992;75: 2964-8. 